Rev. 2

\title{
Guide for Preparing and Maintaining Generator Group Pollution Prevention Program Documentation
}

Prepared for the U.S. Department of Energy Office of Environmental Restoration and Waste Management

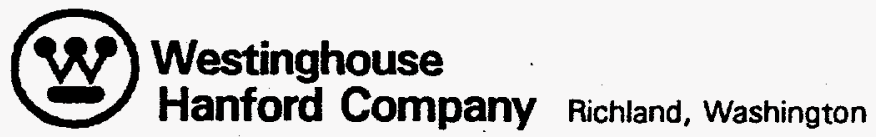

Hanford Operations and Engineering Contractor for the

U.S. Department of Energy under Contract DE-ACO6-87RL10930

Approved for Public Release 


\section{LEGAL DISCLAIMER}

This report was prepared as an account of work sponsored by an agency of the United States Government. Neither the United States Government nor any agency thereol, nor any of their employees, nor any of their contractors, subcontractors or their employees, makes any warranty, express or implied, or assumes any legal liability or responsibility for the accuracy. completeness, or any third party's use or the results of such use of any information, apparatus, product, or process diselosec, or represents that its use would not intringe privately owned rights. Reterence herein to any spesific commercial product, process, or service ty rade name, trademark, manufacturer, or otherwise ones not necassarily constitute or imply its endorsement, recommendation, or lavoring by the United States Government or any agency thereof or its contractors or subcontractors. The views and opinions of authors expressed herein do not necessarily staie or reflect those of ihe United States Government or any agency thereof.

This report has been reproduced from the best available copy. Available in paper copy and microliche.

Available to the U.S. Departmen! of Energy and its contractors irom

Orfice of Scientific and Technica! Information

P.O. $30 \times 62$

Oak Ridge, TN 37831

(615) 576.8401

Available to the public from the U.S. Department of Commerce National Technical Information Service

5285 Port Royal Road

Springfield, VA 22161

(703) $487-4650$

Printed in the Unied States of America

DISCLM-1.CHP $\{1-91\}$ 


\section{DISCLAIMER}

Portions of this document may be illegible in electronic image products. Images are produced from the best available original document. 


\begin{tabular}{|c|}
\hline $\begin{array}{l}\text { Supplemental } \\
\text { Direct Revision } \\
\text { Change ECN } \\
\text { Temporary } \\
\text { Standby } \\
\text { Supersedure } \\
\text { Cancel/Void }\end{array}$ \\
\hline
\end{tabular}

11a. Modification Work

[] Yes (fill out Blk. 11b)

[X] No (NA BIks. 11b, 11c, 11d)
3. Originator's Name, Organization, MSIN, and Telephone No.

B. C. Floyd, WHC Pollution Prevention, 82-22, $376-8467$

5. Project Title/No./Work Order No.

Guide for Preparing and Maintaining Generator Group Pollution Prevention Program Documentation

8. Document Numbers Changed by this ECN (includes sheet no. and rev.) WHC-SD-WM-EV-014, ReV. 1

\begin{tabular}{|c|c|}
\hline $\begin{array}{c}\text { 6. Bldg./Sys./Fac. No. } \\
\text { NA }\end{array}$ & D, E Approval Designator \\
\hline $\begin{array}{c}\text { 9. Related ECN No(s). } \\
\text { NA }\end{array}$ & $\begin{array}{c}\text { 10. Related PO No. } \\
\text { NA }\end{array}$ \\
\hline
\end{tabular}

11b. Work Package 11c. Modification Work Complate No. NA NA 11d. Restored to Original Condition (Temp. or Standby ECK only) NA

Cog. Engineer Signature \& Date

Cog. Engineer signature \& Date

12. Description of Change

Revised and updated Guide for Preparing and Maintaining Facility Waste Minimization plans: included changing document name, reorganizing the document, adding guidance for meeting new pollution prevention budget and goal setting requirements, and updated appendices with model generator program elements, new assessment worksheets, revised reporting forms, and annual schedule.

\begin{tabular}{lllllll}
$\begin{array}{l}\text { 13a. Justification } \\
\text { (mark one) }\end{array}$ & Criteria Change & {$[x]$} & Design Improvement & {[]} & Environmental \\
As-Found & {[]} & Facilitate Const. & {[]} & Const. Error/Omission & {[]} & Design Error/Omission \\
\hline
\end{tabular}

13b. Justification Details

Added in specific pollution prevention budget requirements per Executive Order 12856 , eliminated requirement for preparing facility waste minimization plans, added specific goal setting guidance per DOE guidance. 


\begin{tabular}{|c|c|c|c|c|c|}
\hline $\begin{array}{l}\text { 15. Design } \\
\text { Verification } \\
\text { Required }\end{array}$ & 16. Cost in & & & & 17. Schedul \\
\hline $\begin{array}{l}{[] \text { Yes }} \\
{[\mathrm{X}] \text { No }}\end{array}$ & $\begin{array}{l}\text { Additional } \\
\text { Savings }\end{array}$ & $\$$ & $\begin{array}{l}\text { Additional } \\
\text { Savings }\end{array}$ & $\begin{array}{l}\$ \\
\$\end{array}$ & $\begin{array}{l}\text { Improvement } \\
\text { Delay. }\end{array}$ \\
\hline
\end{tabular}

18. Change Impact Review: Indicate the related documents (other than the engineering documents identified on side 1 ) that will be affected by the change described in Block 12 . Enter the affected document number in Block 19. SDD/DD

Functional Design Criteria Operating Specification Criticality Specification Conceptual Design Report Equipment Spec.

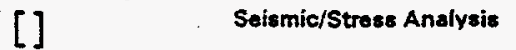

Const. Spoc.

Procurement Spec.

Vendor information

OM Manual

Strescososign Report

[]

[]

Interfaco Control Drawing

Calibration Procedure

[]

Installation Procodure

[]

Maintenance Procedure

[]

Engineering Procedure

[]

Operating Instruction

[]

Operating Procedure

FSAR/SAR

Operational Safety Requirement

Safety Equipment List

IEFD Drawing

[] Tank Calibration Manual

Radiation Work Permit

Environmental Impact Statement

Cell Arrangement Drawing

[]

Essential Matorial Spocification

Environmental Report

Environmental Permit

[] Inventory Adjustment Request

[]

[]

[]

[]

[]

[]

[]

[]

[]

[]

[]

[]

[]

[]

Health Physics Procedure

Spares Multiple Unit Listing

Tost Procedures/Specification

Component index

ASME Coded item

Human Factor Consideration

Computer Sottware

Eloctric Circuit Schedule

ICRS Procedure

Process Contröl Manual/Plan

Process Flow Chart

Purchase Roquisition

19. Other Affected Documents: (NOTE: Documents (isted below will not be revised by this ECN.) Signatures below indicate that the signing organization has been notified of other affected documents listed below.
Document Number/Revision
Document Number/Revision
Document Number Revision

NA

20. Approvals

Signatu
OPERATIONS AND ENGINEERING

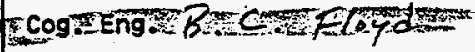

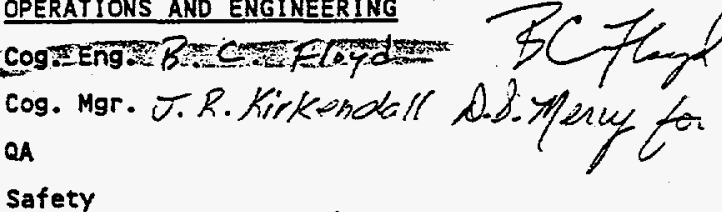

Environ. Dan W.tith D. S. Comrell

other
Date
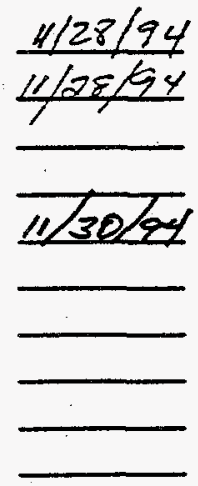

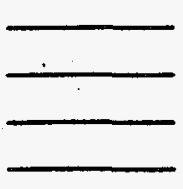

Signature

ARCHITECT -ENGINEER

PE

QA

Safety

Design

Environ.

Other

DEPARTMENT OF ENERGY

signature or a Control Number that

tracks the Approval signature

ADOITIONAL

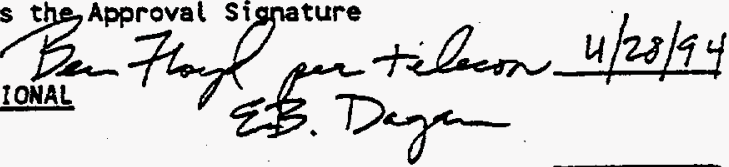




\section{RELEASE AUTHORIZATION}

Document Number: WHC-SD-WM-EV-014, Rev. 2

Document Title: Guide for Preparing and Maintaining Generator Group

Pollution Prevention Program Documentation

Release Date: $\quad 11 / 21 / 94$

This document was reviewed following the procedures described in WHC-CM-3-4 and is:

APPROVED FOR PUBLIC RELEASE

WHC Information Release Administration Specialist:

(hris) Itillingtham

C. Willingham

$11 / 21 / 94$ 


\begin{tabular}{|l|l|c|}
\hline $\begin{array}{l}\text { 2. Title } \\
\text { Guide for Preparing and Maintaining Generator } \\
\text { Group Pollution Prevention Program Documentation }\end{array}$ & $\begin{array}{l}\text { 3. Number } \\
\text { wBC-SD-WM-EV-014 }\end{array}$ & $\begin{array}{c}\text { Rev No. } \\
2\end{array}$ \\
\hline $\begin{array}{l}\text { 5. Key Hords } \\
\begin{array}{l}\text { Pollution Prevention } \\
\text { Waste Minimization }\end{array}\end{array}$ & $\begin{array}{l}\text { 6. Author } \\
\text { Name: B. C. Floyd }\end{array}$ \\
\hline
\end{tabular}

7. Abstract

This manual provides the necessary guidance to waste generator groups (facilities) for developing and maintaining documentation of their pollution prevention and waste minimization activities. Preparation of program documentation will demonstrate compliance with contractor and DOE requirements, as well as state and federal regulations. Generator groups are no longer required to prepare and update facility Waste Minimization plans. Developing and maintaining progran documentation replaces this requirement. The key pollution prevention program elements to be documented are goals; separate and identifiable budget, pollution prevention opportunity assessments, and reporting and opportunity assessment implementation information.

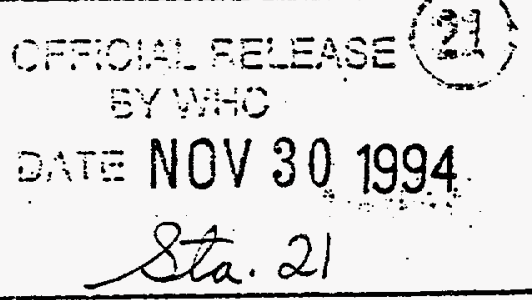


RECORD OF REVISION

(1) Document Number

WHC-SD-WM-EV-014

Page 1

(2) Title

GUIDE FOR PREPARING AND MAINTAINING FACILITY-SPECIFIC WASTE MINIMIZATION PLANS 101724

CHANGE CONTROL RECORO

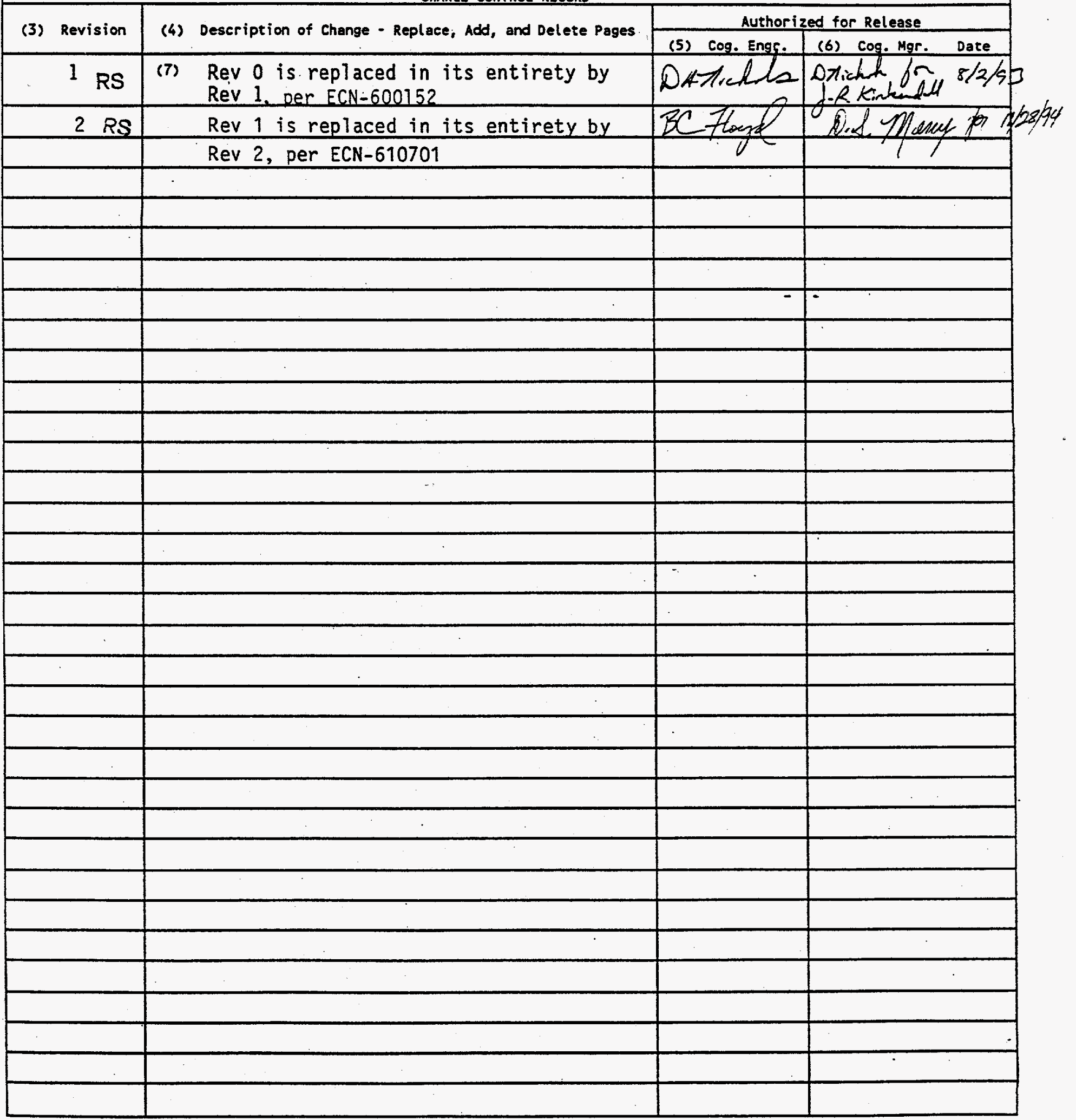


CONTENTS

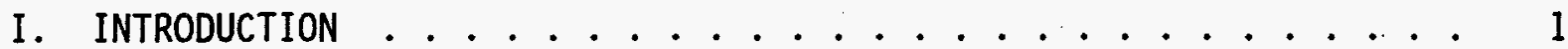

II. POLLUTION PREVENTION PROGRAM DOCUMENTATION . . . . . . . . . 4

A. GOALS . . . . . . . . . . . . 4

B. BUDGET, ACTIVITIES, AND IMPLEMENTATION SCHEDULES $\ldots \ldots$

C. POLLUTION PREVENTION OPPORTUNITY ASSESSMENTS ....... 5

D. POLLUTION PREVENTION REPORTING AND OPPORTUNITY IMPLEMENTATION * 6

III. REFERENCES . . . . . . . . . . . . . . 7

APPENDIX A POLLUTION PREVENTION GOAL SETTING FOR THE HANFORD SITE . . A A-1 APPENDIX B POLLUTION PREVENTION GENERATOR GROUP PROGRAM IMPLEMENTATION

ELEMENTS . . . . . . . . . . . . . . . . . B-1

APPENDIX $C$ WASTE STREAM INFORMATION/PRIORITIZATION AND POLLUTION PREVENTION

OPPORTUNITY ASSESSMENT WORKSHEETS . . . . . . . . . . . . C-1

APPENDIX D WASTE MINIMIZATION/POLLUTION PREVENTION CERTIFICATION FORMS . D-1 APPENDIX E POLLUTION PREVENTION PROGRAM DOCUMENTATION SCHEDULE . . . . E-1

\section{LIST OF FIGURES}

1. Elements and Activities to be Documented in a Generator Group

Pollution Prevention Program ............... 2

2. Pollution Prevention Program Documentation Matrix ....... 3 
WHC-SD-WM-EV-014, Rev. 2

\section{ACRONYMS}

CAP
DOE
ECology
EPA
MYPP
F2
P2OA
RCRA
SARA
WAC
WHC

Cost Account Plan

U.S. Department of Energy

Washington State Department of Ecology

Environmental Protection Agency

Multi-Year Program Plan

Pollution Prevention

Pollution Prevention Opportunity Assessment

Resource Conservation and Recovery Act of 1976

Superfund Amendments and Reauthorization Act of 1986

Washington Administrative Code

Westinghouse Hanford Company 
WHC-SD-WM-EV-014, Rev. 2

\section{GLOSSARY}

Generator Group - As defined by the responsible contractor, any discrete activity, project, or facility whose act or process produces waste.

Goal - A specific result toward which processes are directed.

Hazardous Waste - Waste, which because of its quantity, concentration and physical, chemical, or infectious characteristics may cause, or significantly contribute to an increase in mortality, or may pose a potential hazard to human health or the environment when improperly treated, stored, transported, or disposed of, or otherwise managed. See Resource Conservation and Recovery Act of 1976 (RCRA) Regulated Waste and State-Only Regulated Waste (DOE, 1994a).

High-Level Waste (HLW) - Irradiated reactor fuel, liquid wastes resulting from the operations of the first cycle solvent extraction system, or equivalent, and the concentrated wastes from subsequent extraction cycles, or equivalent, in a facility for reprocessing irradiated reactor fuel, and solids into which such liquid wastes have been converted (DOE, 1994a).

Low-Level Waste (LLW) - Radioactive waste not classified as HLW, transuranic (TRU) waste, spent nuclear fuel, or by-product material (specified as uranium or thorium tailings and waste in accordance with DOE Order 5820.2A) (DOE, 1994a).

Mixed Waste - Waste that contains both radioactive (as defined by the Atomic Energy Act of 1954) and hazardous (as defined by RCRA, Toxic Substances Control Act (TSCA), and/or state regulations) components (DOE, 1994a).

Non-routine activities - One-time operations waste: wastes produced from environmental restoration program activities, including primary and secondary wastes associated with retrieval and remediation operations; "legacy wastes;" and D\&D/Transition operations. It also includes all TSCA-regulated wastes, such as PCB-contaminated fluids and/or equipment. By definition, these activities are not considered to be periodic and/or ongoing, because the waste is a direct result of past operations and activities, rather than a current process. However, newly generated wastes that are produced during these "onetime operations" are considered to be a secondary waste stream, and should be separately accounted for whenever possible. This secondary (newly generated) waste usually results form common activities such as handling, sampling, treatment, repackaging, shipping, etc (DOE, 1994a).

Metric - A standard of measurement (such as length, area, frequency, etc).

Performance Measure - An objective, quantitative system for rating the quality of an activity or service based on a desired set of improvement objectives.

Process Waste water - Any water produced during manufacturing or processing operations that comes into direct contact with or results from the production or use of any raw material, intermediate product, finished product, byproduct, or waste product. This determination is independent of the level and/or nature of the contaminants. Additionally, process waste waters are 
liquid wastes, which are directly piped to a permitted (onsite) waste treatment facility, where treatment may consist of neutralization, evaporation, or placement in a settling or percolation pond, etc. This term does not include the liquid discharges to Publicly Owned Treatment Works, which are governed by EPA- or State-issued NPDES permits, or local pretreatment standards.

Examples of process waste water include cooling water from air compressor systems, air conditioners, and heating systems; boiler or cooling tower blowdown; ion-exchange regeneration. waste water; and laboratory operations waste water. It does NOT include non-process waste waters such as stormwater, well purge water, irrigation drainage, fire-fighting and hydrant flushings, lawn watering, pavement wash waters, vehicle waste water, etc. (DOE, 1994a).

RCRA Regulated Waste - Solid waste, not specifically excluded from regulations under 40 CFR 261.4, or delisted by petition, that is either a listed hazardous waste (40 CFR 261.30-261.33) or exhibits the characteristics of a hazardous waste (40 CFR 261.20 - 261.24).

Routine activities - Normal operations waste: waste produced from any type of production operation, analytical and/or research and development (R\&D) laboratory operations; treatment, storage, disposal operations, "work-forothers," or any other periodic and recurring work that is considered on-going in nature. The term "normal operations" refers to the type of on-going process (i.e., production, R\&D, etc.), not the specific activity that produced the waste. Periodic laboratory or facility clean-outs and spil1 clean-ups which occur as a result of these processes are also considered normal operations (DOE, 1994a).

Sanitary Waste - Wastes such as garbage, that are generated by normal housekeeping activities and are not hazardous or radioactive (DOE, 1994a)

Spent Nuclear Fuel - Fuel that has been withdrawn from a nuclear reactor following irradiation, but that has not been reprocessed to remove its constituent elements. (DOE Order 5820.2A)

State-Only Regulated Waste - Any other hazardous waste not specifically regulated under TSCA or RCRA, such as used 011 , which may be regulated by a State or local authority (DOE, 1994a).

Transuranic Waste - Waste that is contaminated with alpha emitting radionuclides with an atomic number greater than 92 (heavier than uranium); half 7 ives greater than 20 years; and concentrations greater than 100 nanocuries per gram of waste (DOE, 1994a).

TSCA Regulated Waste - Hazardous chemical wastes, both liquid and solid, containing more than 50 parts per million of polychlorinated byphenyls (DOE, 1994a). 
WHC-SD-WM-EV-014, Rev. 2

I. INTRODUCTION

The Hanford Pollution Prevention (P2) program is an organized, comprehensive, and continual effort to: systematically reduce the quantity and toxicity of hazardous, radioactive, mixed, and sanitary wastes; conserve resources; and prevent or minimize pollutant releases to all environmental media from all Hanford Site activities. The program has been developed to meet waste minimization and pollution prevention public law requirements, federal and state regulations, and U.S. Department of Energy (DOE) requirements. The Hanford P2 program is implemented through the sitewide, contractor, and generator group programs.

This manual provides the necessary guidance to waste generator groups (facilities) for developing and maintaining documentation of their P2 program activities. Preparation of program documentation will demonstrate compliance with contractor and DOE requirements, as well as state and federal regulations. Generator groups are no longer required to prepare and update Facility Waste Minimization plans. Developing and maintaining program documentation replaces this requirement.

Historically, Hanford waste generating and treatment, storage, and disposal facilities prepared and issued waste minimization plans containing general and facility-specific information to guide and document their program activities. This planning approach was analyzed to determine ways additional emphasis could be placed on the development and integration of goals, activities, and budgets to achieve $P 2$ results and ways the planning and program documentation process could be streamlined and still meet regulatory and DOE requirements. The new approach achieves these objectives in two important ways.

First, the general P2 information common to all facility plans is now contained in the Site and contractor plans. Generator groups are now required to only have documentation on key pollution prevention elements and activities within their programs. The DOE-Richland Operations Office (RL) P2 program manager has determined these key elements to be:

- Goals

- Separate, identifiable budget

- Pollution prevention opportunity assessments (P20A)

- Reporting and P2OA implementation.

The specific activities to be documented under these headings are presented in Figure 1. P2 program documentation will be on file at a facility to demonstrate compliance with regulatory, DOE, and contractor requirements.

Second, this approach also documents at the Site, contractor, and/or generator group level, all of the suggested program elements in the Environmental Protection Agency (EPA) guidance for a Resource Conservation and Recovery Act of 1976 (RCRA) compliant waste minimization program (EPA 1993). Figure 2 identifies where each program element is documented. The Washington State Department of Ecology (Ecology) has also determined this approach will meet the intent of the Washington Administrative Code (WAC) 173-307. 
Figure 1. Elements and Activities to be Documented in a Generator Group Pollution Prevention Program

1. Goals on Waste Types, Pollutants, and Hazardous Chemicals

- Five-year forecast and annual goals

- Source reduction

- Recycling

- Pollution prevention opportunity assessments (P20A)

- Environmental Compliance Officer and responsible management signatures

2. Separate, Identifiable Budget, Activities, and Schedule

- Budget supporting P2 activities, deliverables, and milestones identified in Multi-Year Program Plans (MYPP)

3. Pollution Prevention Opportunity Assessments

- Summary waste stream prioritization information

- Waste stream information

- Priority waste streams and activities

- Pollution prevention opportunity assessment

- Team and activity description

- Activity flow diagram

- Pollution prevention opportunity description

- Pollution prevention opportunities summary

- Final summary

4. Pollution Prevention Reporting and Implementation

- Quarterly reports (3)

- Status on goals

- Report on accomplishments and P20A implementation progress

- Senior management signature

- Annual report

- Status on achieving annual goals

- Status on meeting (or adjustments to) five-year forecast

- Next calendar year goals

- Report on accomplishments and P20A implementation progress

- Waste Minimization/Pollution Prevention Certification Form

A. Annual certification with senior management signature

B. Waste reduction on specific waste streams 
Figure 2. Pollution Prevention Program Documentation Matrix

\begin{tabular}{|c|c|}
\hline $\begin{array}{c}\text { EPA GUIDANCE* } \\
\text { WASTE MINIMIZATION PROGRAM ELEMENTS } \\
\text { (PER RCRA) }\end{array}$ & PROGRAM DOCUMENTATION \\
\hline \multicolumn{2}{|l|}{ A. TOP MANAGEMENT SUPPORT } \\
\hline Hanford Site policy & Hanford Site plan \\
\hline Company policy & Contractor plans \\
\hline Goals & $\begin{array}{l}\text { Hanford Site } \mathrm{plan} \text {, Contractor } \mathrm{plans} \\
\text { Generator group program } \\
\text { documentation }\end{array}$ \\
\hline $\begin{array}{l}\text { Commitment - opportunity } \\
\text { implementation }\end{array}$ & Hanford Site plan, Contractor plans \\
\hline Facility coordinator & Contractor plans \\
\hline Publicize successes & Hanford Site $p l a n$, Contractor $p l a n s$ \\
\hline Incentives & Hanford Site plan, Contractor plans \\
\hline Training & Hanford Site plan, Contractor plans \\
\hline $\begin{array}{l}\text { B. CHARACTERIZATION OF WASTE } \\
\text { GENERATION }\end{array}$ & Contractor plans \\
\hline \multicolumn{2}{|l|}{ C. OPPORTUNITY ASSESSMENTS } \\
\hline Identify all opportunities & $\begin{array}{l}\text { Contractor plans } \\
\text { Generator group program } \\
\text { documentation }\end{array}$ \\
\hline Determine true costs of the waste & $\begin{array}{l}\text { Contractor plans } \\
\text { Generator group program } \\
\text { documentation }\end{array}$ \\
\hline D. COST ALLOCATION SYSTEM & Hanford Site plan, contractor plans \\
\hline E. TECHNOLOGY TRANSFER & Hanford Site plan, contractor $\mathrm{plans}$ \\
\hline F. PROGRAM EVALUATION & $\begin{array}{l}\text { Hanford Site plan, contractor plans } \\
\text { Generator group program } \\
\text { documentation }\end{array}$ \\
\hline
\end{tabular}

* Federal Register /Vol. 58, No. 102/ Friday, May 28, 1993 
WHC-SD-WM-EV-014, Rev . 2

\section{POLLUTION PREVENTION PROGRAM DOCUMENTATION}

The following information has been developed to assist generator groups in developing and maintaining quality and current documentation of their P2 program activities. All program documentation should be maintained at a central location within the facility.

\section{A. GOALS}

The development of goals and performance measures is an important element of the Hanford P2 Program. Pollution prevention goals are necessary to (1) meet federal, state, and DOE regulations and reporting requirements, (2) provide a system for tracking progress and measuring success of our pollution prevention activities, and (3) focus efforts on results-oriented, achievable activities that reduce the generation of waste and pollutants to all media, the use of hazardous substances, and the conservation of energy and natural resources.

\section{Goal Setting Requirements:}

The establishment of pollution prevention goals is required for Hanford Site waste generator groups. Setting goals will be divided into two parts and all goals will be established by calender year.

Part 1: Waste generator groups will develop a five-year forecast for source reduction, recycling, the number of P2OAs to be conducted, and planned reduction in use and release of Emergency Planning and Community Right-to-Know Act (EPCRA) toxic chemicals (where applicable). Five-year forecasts are due to the Westinghouse Hanford Company (WHC) P2 group by January 15th of each year and must be signed by the facility Environmental Compliance Officer (ECO) and manager responsible for the waste generating activities.

Part 2: Annual goals will then be submitted every year based on specific reduction activities and P20As planned for that year. These specific annual goals will be performance-oriented and based on the unit of output or work of your choice. These annual goals are due to the WHC Pollution Prevention group by January 15 of every year and should also be signed by your ECO and responsible manager. As done previously, reports that status progress towards your annual goals and P20As sha71. be submitted on a quarterly basis.

Goal setting guidance and forms for establishing the five-year forecast and annual goals are in Appendix $A$ of this document. The guidance contains specific details and instructions on setting goals and developing performance measures to track and measure progress towards achieving goals. 


\section{B. BUDGET, ACTIVITIES, AND IMPLEMENTATION SCHEDULES}

\section{Pollution Prevention Budget Requirements}

Pollution prevention budget reporting requirements contained in Executive Order 12856 (1993) and the Office of Management and Budget (OMB) Circular A-106 Pollution Abatement Report mandate that all federal agencies identify, request, and allocate funds for implementing pollution prevention and abatement strategies within their operations (DOE 1994b).

DOE planning and budgeting guidance states these requirements will be met through the establishment of separate, identifiable pollution prevention funding (DOE 1994b). Separate, identifiable funding established at the generator group level will be consolidated for the Site to meet DOE reporting requirements for the DOE Annual Report and Waste Generation and Waste Minimization Progress. The budgeting guidance also identifies the specific P2 program elements generator groups should budget for. These program elements are the key generator group elements identified in the DOE Waste Minimization/Pollution Prevention Crosscut plan (1994c). These program elements and a description of the activities within the scope of these program elements are listed in Appendix B.

\section{Pollution Prevention Budgeting}

During the preparation of the MYPP and activity data sheets (ADS), separate, identifiable pollution prevention budgets will be established. Generator groups will identify budget for their program activities in these budget documents. Emphasis should be placed on budgeting for those activities that will help generator groups achieve their goals. Separate, identifiable funding can be established within individual cost account plans (CAP) at the CAP, work, or task package level--depending upon the size of the pollution prevention budget and the organization of the generator group program. Copies of the appropriate budget documentation will be maintained as program documentation. In cases where funding is not established in separate budget documents, estimated budget information should be maintained as documentation.

\section{POLLUTION PREVENTION OPPORTUNITY ASSESSMENTS}

An important part of an effective P2 program is the identification and prioritization of waste streams, the connection of waste streams to specific activities, and then performing P2OAs on these activities. Worksheets to document the identification and prioritization of generator group waste streams and for the conducting of a P2OA are included in Appendix $C$ of this document and are also available on the Hanford Local Area Network (HLAN) as macros GEF 290 - 296. The assessment will provide a basis for identifying specific modifications to facility waste generating activities needed to achieve the five year and annual goals. Completed P20As on file at the facility will serve as documentation to meet $P 2$ program requirements. Training on how to conduct a P2OA is available from WHC Pollution Prevention. The Pollution Prevention Opportunity Assessment--Guidance for the Hanford Site is also available to help generator groups complete these activities (WHC 1994). 


\section{POLLUTION PREVENTION REPORTING AND P2OA IMPLEMENTATION}

Reports will be made quarterly and annually to the WHC P2 group. Quarterly reports are due the 15th of April, July, and October. The reports can be in the form of a letter with attachments and should address (1) progress toward achieving annual goals, including the percent reduction achieved, the method used to achieve goals, and cost savings, (2) copies of completed P20As, (3) progress in implementing opportunities identified from P2OAs, and (4) other pollution prevention accomplishments not connected with specific goals. An example of other accomplishments could be the revision of a procedure resulting in improved material handling practices.

On January 15 of each year, a detailed annual report shall be made on the accomplishment of annual goals, progress toward achieving five-year forecasts, and completed Waste Minimization/Pollution Prevention Certification Reporting forms. The report should identify any adjustments in the forecast and identify goals for the next calendar year. Copies of completed P20As, progress in implementing opportunities identified from P2OAs, and other pollution prevention accomplishments not connected with specific goals should be included.

The Waste Minimization/Pollution Prevention Certification form is for generator groups to identify whether they reduced waste during the reporting period and to certify the waste minimization information being reported is true and accurate. These forms are included in Appendix D. The form is also for generator groups to provide a summary of previous calendar year waste reduction efforts. This information will be used to report waste minimization activities to DOE, Ecology, and EPA.

A schedule for submitting the annual and quarterly reports is attached as Appendix E. The schedule also identifies schedules and due dates for preparing annual goals and budgets and other key activities to maintain up-todate program documentation. 
WHC-SD-WM-EV-014, Rev. 2

\section{REFERENCES}

Benedict, M.B., 1994, Letter to D.S. Merry, Washington State Department of Ecology, Yakima, Washington

DOE, 1988, Radioactive Waste Management, DOE Order 5820.2A, U.S. Department of Energy, Washington, D.C.

DOE, 1994a, Waste Minimization Reporting System (WMINRS version 2.0) Users Manual, U.S. Department of Energy, Washnington, D.C.

DOE, 1994b, Budget Formulation and Activity Data Sheet Development-Supplemental Field Guidance for the FY 1996 Planning and Budgeting Cyc7e. U.S. Department of Energy, Washington, D.C.

DOE, 1994c, Waste Minimization/Pollution Prevention Crosscut Plan, U.S Department of Energy, Washington, D.C.

DOE-RL, 1994, Hanford Site Waste Minimization and Pollution Prevention Awareness Program Plan, DOE/RL-91-31, Rev. 1, U.S. Department of Energy, Richland, Washington.

Ecology, 1991, Pollution Prevention Planning: Guidance Manual for Chapter 173-307 WAC, Publication 91-2, Washington State Department of Ecology, 0lympia, Washington.

EPA, 1993, Guidance to Hazardous Waste Generators on the Elements of a Waste Minimization Program. Federal Register. Vol. 58, No. 102. Washington, D.C.

Executive Order 12856, 1993, "Federal Agency Compliance with Community Rightto-Know Laws and Pollution Prevention Requirements, "Federal Register, Vol. 58, pp. 41981, (August).

Executive Order 12873, 1993, "Federal Acquisition, Recycling and Waste Prevention," Federal Register, Vol. 58, pp. 54911, (October).

Emergency Planning and Community Right-to-Know Act, as amended, 42 USC 11013, 11028 , et seq.

Pollution Prevention Act of 1990, 42 U.S.C. 13101 et seq.

Resource Conservation and Recovery Act of 1976, 42 USC 6901 et seq.

Superfund Amendments and Reauthorization Act of 1986, 42 U.S.C. 11001 et seq.

WAC 173-307, 1991, "Pollution Prevention Plans," Washington Administrative Code.

WHC, 1994A, Pollution Prevention Opportunity Assessiments--Guidance for the Hanford Site, WHC-MR-0472, Westinghouse Hanford Company, Richland, Washington. 
WHC-SD-WM-EV-014, Rev. 2

This page intentionally left blank. 
WHC-SD-WM-EV-014, Rev. 2

APPENDIX A

POLLUTION PREVENTION GOAL SETTING FOR THE HANFORD SITE

\section{Introduction:}

The development of goals and performance measures is an important element of the Hanford P2 Program. Pollution prevention goals are necessary to (1) meet Federal, state, and DOE regulations and reporting requirements, (2) provide a system for tracking progress and measuring success of our pollution prevention activities, and (3) focus efforts on results-oriented, achievable activities that reduce the generation of waste and pollutants to all media, the use of hazardous substances, and the conservation of energy and natural resources.

\section{Goal Setting Requirements:}

Establishing pollution prevention goals is required for Hanford Site waste generator groups. Setting goals will be divided into two parts.

Part 1: Waste generator groups wi11 develop a five-year forecast for source reduction, recycling, the number of P20As to be conducted, and planned reduction in use and release of EPCRA toxic chemicals (where applicable). Five-year forecasts are due to the P,2 Program by January 15th every year and must be signed by the facility ECO and manager responsible for the waste generating activities.

Part 2: Annual goals will then be submitted every year based on specific reduction activities and P20As planned for that year. These specific annual goals will be performance-oriented and based on the unit of output or work of your choice. These annual goals are due to the P2 Program by January 15 of every year and should also be signed by your ECO and responsible manager. As done previously, reports that status progress towards your annual goals and P20As shall be submitted on a quarterly basis.

A11 goals set will be based on the waste generated by your facility or activities in calendar year 1993. Waste generation information for most waste streams can be obtained from the Solid Waste Information Tracking System (SWITS) and is tracked by waste type and generator group. 0ther non-SWITS waste streams, such as sanitary waste and liquid waste sent to the tank farms may need to be tracked separately. EPCRA hazardous material usage can be obtained from your previous year's EPCRA 313 report. The 1993 baseline may not accurately reflect the waste generated by your activities or your facility, but you will have a chance to explain unusual circumstances affecting your goals on an annual basis.

It is understood that for the current work being done at the Hanford Site very few activities are "routine" enough to easily set five-year forecasts for waste reduction and that in future years more waste may actualiy be generated than minimized. Try to base your five-year forecasts on the best waste projections available. Each year that you submit annual goals you will have an opportunity to adjust or change these five-year forecasts when you know more clearly what work will be conducted for the year. Your five-year waste 
reduction forecasts should be compared with any reduciton shown in your solid Waste Forecast.

DOE-Headquarters $(H Q)$ does allow for the development of qualitative five-year forecasts rather than quantitative for non-routine waste generating activities. Non-routine activities are those associated with environmental restoration and decontamination and decommissioning (D\&D). It is believed, however, that the quantitative annual goal setting of Part 2 can be applied to both routine and non-routine activities.

Specific details and instructions on goal setting are found in the following pages. Tables are provided for the five-year forecasts required in Part 1 and example worksheets are provided for the annual goals required in Part 2. A glossary of definitions is included for your use at the beginning of this document. 


\section{Part 1. Preparing Five-Year Pollution Prevention Forecasts}

The preparation of Tables 1,2, and 3 on the following page are required by the DOE for the Annual Waste Generation and Waste Minimization Report. By establishing and reporting against these goals, the DOE is ensuring compliance with the RCRA requirements for a Waste Minimization Program, the Washington State Pollution Prevention Planning requirements, and recently issued Executive Orders on EPCRA toxic chemical reduction, ozone-depleting substances, sanitary waste prevention, and energy and water conservation.

\section{Instructions:}

Table 1: For each year and waste type listed on the table, please estimate the percentage of waste you expect to reduce due to source reduction activities such as product substitution, procedure change, equipment modification, housekeeping, etc. Percentage of waste reduced should be by volume or weight as noted in Table 1. If you do not generate a certain waste type, do not use a priority EPCRA hazardous material, or do not expect to generate that waste in upcoming years, write not applicable or N/A in the column. These forecasts are based on the waste generated at your facility or by your activities in calendar year 1993 .

These are your five-year forecasts and it is suggested that you just make the best estimate possible at this time. Each year you submit annual goals you will have a chance to revise or remark on the five-year forecasts you set in this section.

These five-year forecasts will be weighted by the waste generated at each facility and then aggregated to determine sitewide goals. The percentages you estimate in this table will be a part of the sitewide goals listed in annual reports and the Hanford Site Waste Minimization and P2 Awareness Plan.

Table 2: Executive Orders issued in 1993 have mandated that separate recycling goals be set for Hazardous and Sanitary waste and Process Waste water. For each year and waste type listed in the table, please estimate the percentage of waste you expect to reduce due to recycling, reclamation, or reuse activities. Again, it is understood that these will be a best estimate and you will have a chance to revise these on an annual basis. Five-year recycling forecasts will be rolled up and included in annual reporting for the Hanford Site.

Table 3: P20As are the main mechanism by which waste generator groups will demonstrate that an active waste minimization program is in place. The two activities required for P2 Program compliance are Annual Goals and P20As. Please fill out the number of P20As to be conducted during the next five years. Every year at least one P20A should be conducted. Also note any funding requested for pollution prevention on the outyears. 
WHC-SD-WM-EV-014, Rev. 2

Table 1 Source Reduction Forecasts for CY 1995 - 1999

\begin{tabular}{|c|c|c|c|c|c|}
\hline Waste Type & cy 1995 & cr 1996 & CY 1997 & CY 1998 & CY 1999 \\
\hline \multicolumn{6}{|l|}{ Low-Level Waste $(L L W)\left(m^{3}\right)$} \\
\hline \multicolumn{6}{|l|}{ Transuranic Waste $(T R U)\left(m^{3}\right)$} \\
\hline High-Level Waste $(H L W)\left(m^{3}\right)$ & N/A & $N / A$ & N/A & N/A & N/A \\
\hline Low-Level Mixed Waste $(L L H-M)\left(m^{3}\right)$ & $\begin{array}{l}(s) \\
(1)\end{array}$ & $\begin{array}{l}\text { (s) } \\
(1)\end{array}$ & $\begin{array}{l}\text { (s) } \\
(1)\end{array}$ & $\begin{array}{l}(s) \\
(1)\end{array}$ & $\begin{array}{l}(s) \\
(1)\end{array}$ \\
\hline \multicolumn{6}{|l|}{ Transuranic Mixed Haste (TRU-M) $\left(\mathrm{m}^{3}\right)$} \\
\hline \multicolumn{6}{|l|}{ RCRA Hazardous Waste $(\mathrm{kg})$} \\
\hline \multicolumn{6}{|l|}{ State-Only Hazardous Waste $(\mathrm{kg})$} \\
\hline \multicolumn{6}{|l|}{$\begin{array}{l}\text { Toxic Substances Control Act Waste } \\
\text { (TSCA) Regulated Waste (kg) }\end{array}$} \\
\hline \multicolumn{6}{|l|}{ Sani tary (kg) } \\
\hline \multicolumn{6}{|l|}{$\begin{array}{l}\text { Process Waste water }\left(\mathrm{m}^{3}\right) \\
\text { - Radioact ive } \\
\text { - Mixed } \\
\text { - Hazardous } \\
\text { - Non-regulated } \\
\end{array}$} \\
\hline EPCRA 313 substances (kg) & & & & & \\
\hline
\end{tabular}

Table 2 Recycling Forecasts for CY 1995 - 1999

\begin{tabular}{|c|c|c|c|c|c|}
\hline Waste Type & CY 1995 & CY 1996 & cY 1997 & cy 1998 . & CY 1999 \\
\hline \multicolumn{6}{|l|}{ RCRA Hazardous Waste $(\mathrm{kg})$} \\
\hline \multicolumn{6}{|c|}{ State-Only Hazardous Waste $(\mathrm{kg})$} \\
\hline \multicolumn{6}{|c|}{$\begin{array}{l}\text { Toxic Substances Control Act Waste } \\
\text { (kg) (TSCA) Regulated Waste }\end{array}$} \\
\hline \multicolumn{6}{|l|}{ Sanitary $(\mathrm{kg})$} \\
\hline $\begin{array}{l}\text { Process Waste water }\left(\mathrm{m}^{3}\right) \\
\text { - Hazardous } \\
\text { - Non-regulated }\end{array}$ & & & & & \\
\hline
\end{tabular}

Table 3 Pollution Prevention Opportunity Assessments (P20As) Planned and Conducted for CY 1995 - 1999

\begin{tabular}{|l|c|c|c|c|c|}
\hline \multicolumn{1}{|c|}{ P2OA } & CY 1995 & CY 1996 & CY 1997 & CY 1998 & CY 1999 \\
\hline Number of PZOAS & & & & & \\
\hline Funding Requested & & & & & \\
\hline
\end{tabular}


WHC-SD-WM-EV-014, Rev. 2

Part 2. Annual Pollution Prevention Goal Setting and Measuring Progress

\section{Instructions:}

Step 1. Summarize Annual Goals and P20As

Annual goals should be correlated to the waste types that you plan to minimize, identified in Tables 1 and 2, and the number of P2OAs you are going to conduct, identified in Table 3. Pull this information from Tables 1, 2, and 3 for the current year and fill in the corresponding blanks in Table 4 below. Using Table 3, fill in the column marked "P20A" with a check mark to indicate if you will be conducting a P2OA on that waste stream. Add the number of check marks and indicate in the space provided at the top of the table the total number of P20As you plan to perform during the year. Also estimate the number of P2 opportunities, identified from P20As or other sources, you plan to implement during the calendar year.

Current Calendar Year:

Total Number of P2OAs to be Performed in $\mathrm{CY}$ :

Total Number of P2 Opportunities to be implemented in CY:

Table 4. Summary of Goals and P2OAs for Calendar Year 199X
Waste Type Source Reduction Recycling P20A?
LLW
TRU
HLW
LLW-M
TRU-M
RCRA Hazardous
State-Oniy
TSCA
Sanitary
Process Waste

\section{Step 2. Develop Performance Measures}

Annual goals will be specific, performance-oriented, and based on the work that you do or the services you provide at the Hanford Site. The idea is to break down the goals you set in the five-year forecast into specific, measurable, and achievable goals that will help you document success achieved in preventing pollution. These goals will be chosen by your organization and will be based on a unit of work or output of your choice. They will be tracked on a quarterly basis. 
WHC-SD-WM-EV-014, Rev. 2

To identify the performance measure(s) for your organization please provide the following information. It is important to make this as broad as possible. Each answer should only be one line or more. A blank Annual Goals Worksheet is also include as Attachment 1. Example goals, lists of pollution prevention activities, and metrics are included for your use as Attachments 2 and 3 , respectively.

\section{Annual Goals Information}

Facility: Identify the Facility or Waste Generating Group that the Annual Goals will cover

Key Processes or Activities: Identify what it is that you do at the Hanford Site. What is the description of the work you do or the service you provide, be it "environmental restoration, facility maintenance, computer user-support, etc."

Key Products, Output(s), or Work of your organization: Identify what it is that your organization receives funding to do. What is the deliverable(s), the product(s), service(s), or output(s)? Examples include: decontaminated equipment, serviced vehicles, clean and well-maintained buildings, data, pilot-scale study results, etc.

This unit of work should be something that is broad enough to cover your work activities for the next five years. It would be beneficial to keep the same unit of work or output over the five years in order to track progress for the entire time period. However, this unit can vary from year to year, based on your facility needs.

Annual Goals:

Annual goals set here will have the following format of Pollution Prevention Activity to be achieved for every unit of work or service provided on a calendar year basis.

Goals should be results-oriented (described in the paste tense), realistic or attainable, and measurable. You may set as many goals as you like, but a minimum of two per year are required.

Measures: Measures compare the results of the pollution prevention activity with the unit of output or measure of success for your organization. List of pollution prevention activities and performance measures are included here for your use in generating ideas.

Metrics: Metrics are just the specific units of measure for the pollution prevention activity compared with the unit or work, output, or service. Examples of metrics are also included for each of the pollution prevention activities or unit of outputs listed for your use. 
WHC-SD-WM-EV-014, Rev. 2

\section{Pollution Prevention Annual Goals}

Attachment 1

Facility:

Key Processes or Activities:

Key Products in Our System:

Goals:

(1)

(2)

(3)

Measures:

(1)

(2)

(3)

Metrics:

(1)

(2)

(3) 


\section{EXAMPLE:}

Facility: D\&D/Environmental Restoration

Objectives:

Improved Cost Effectiveness

Prevented Pollution to All Media and Conserved Energy and Natural Resources

Improved Environment, Safety, and Health for workers and community

Key Activities:

Environmenta7 Cleanup

Decontamination

Decommissioning

\section{Key Products:}

Sites remediated and/or restored

Facilities/sites/equipment cleaned for released or disposal

Buildings/areas demolished

Goals:

(1) To keep the rate of waste generation per square feet of area remediated to a ratio of $1: 4$.

(2) To free release $50 \%$ of a 11 equipment decontaminated this year.

(3) Segregate and recycle up to $50 \%$ of all materiat collected from decommissioning this year.

\section{Measures:}

(1) Waste generated compared to meters cubed area remediated.

(2) Equipment released to total equipment decontaminated.

(3) Material recycled per meters cubed building decommissioned.

\section{Metrics:}

(1) Mass waste $/ \mathrm{m}^{3}$.

(2) Mass equipment released/mass equipment decontaminated

(3) Mass recycled $/ \mathrm{m}^{3}$ 
Generic Pollution Prevention Activities and Corresponding Metrics

Activity

Generation of Waste Reduced

Scrap metal recycled

Trained employees

Decontaminated equipment

Hazardous material purchases controlled

Inventory of hazardous products reduced

Radiologically controlled areas reduced

Procedures changed
Metric

$\mathrm{kg} / \mathrm{m}^{3}$

$\mathrm{kg}$

Number of trained people

$\mathrm{kg} / \mathrm{m}^{3}$

Number of purchases

$\mathrm{kg}$

square meters

Number of procedures or $\mathrm{kg}$ waste minimized 
WHC-SD-WM-EV-014, Rev. 2

This page intentionally left blank. 


\section{APPENDIX B}

\section{POLLUTION PREVENTION GENERATOR GROUP PROGRAM IMPLEMENTATION ELEMENTS}

\section{Organization and Infrastructure}

- Designate a generator group P2 Coordinator

- Interface with the sitewide P2 Coordinator(s) and Headquarters

- Participate in the sitewide P2 Committee and Coordinator Network, and.

- Institute corrective actions resulting from program evaluation.

\section{Site/Facility Program Development}

- Develop and maintain generator group P2 program documentation

- Develop P2 program objectives and establish quantitative and qual itative goals,

- Develop activity schedules for specific tasks and projects,

- Formulate budgets for generator group programmatic activities,

- Assign personnel to develop and implement the generator group P2 program, and

- Integrate P2 practices into site operating procedures.

3. Sitewide Training

- Involve employees in job-specific P2 practices;

- Exchange information and technologies with other waste generator groups;

- Seek technical assistance from the sitewide program;

- Track material use, waste generation rates, and recycling rates;

- Report on material usage, waste generation, recycling, and progress made due to implementing P2 practices; and

- Participate in sitewide source reduction and recycling programs.

\section{Site/Facility Training}

- Provide job-specific training and

- Participate in opportunity assessment and implementation training. 


\section{WHC-SD-WM-EV-014, Rev. 2 \\ POLLUTION PREVENTION GENERATOR GROUP \\ PROGRAM IMPLEMENTATION ELEMENTS}

\section{Opportunity Assessments}

- Identify and evaluate current and potential waste generating activities,

- Identify and prioritize P2 opportunities, and

- Identify research and development needs.

6a Implement Source Reduction Opportunities for Hazardous, Radioactive, and Mixed Waste. Streams

- Modify processes to reduce hazardous and radioactive waste generation,

- Substitute materials to reduce toxic chemical use and release

- Substitute materials to reduce hazardous and radioactive waste generation,

- Procure capital equipment to implement P2 opportunities, and

- Conduct Research, Development, and Demonstration on difficult to manage waste streams.

5b Implement Recycling Opportunities for Hazardous, Radioactive, and Mixed Waste Streams

- Reuse or recycle hazardous and radioactive wastes on-site and

- Recycle hazardous wastes off-site.

6c Implement Source Reduction and Recycling Opportunities for Sanitary Waste Streams

- Use affirmative procurement practices to encourage the purchase and use of recovered materials, and

- Reuse or recycle sanitary wastes.

7. Design Considerations

- Design P2 principles and practices into new facilities,

- Incorporate P2 into facility upgrades and process modifications, and

- Evaluate the potential of new technologies on waste generating activities.

\section{Program Evaluation}

- Evaluate generator group program implementation status and

- Evaluate effect of source reduction and recycling on waste generation and disposal rates. 
WHC-SD-WM-EV-014, Rev. 2

\section{APPENDIX C}

WASTE STREAM INFORMATION/PRIORITIZATION

AND POLLUTION PREVENTION OPPORTUNITY ASSESSMENT WORKSHEETS 
WHC-SD-WM-EV-014, Rev. 2

This page intentionally left blank. 
WHC-SD-WM-EV-014, Rev. 2

\section{Waste Stream Information}

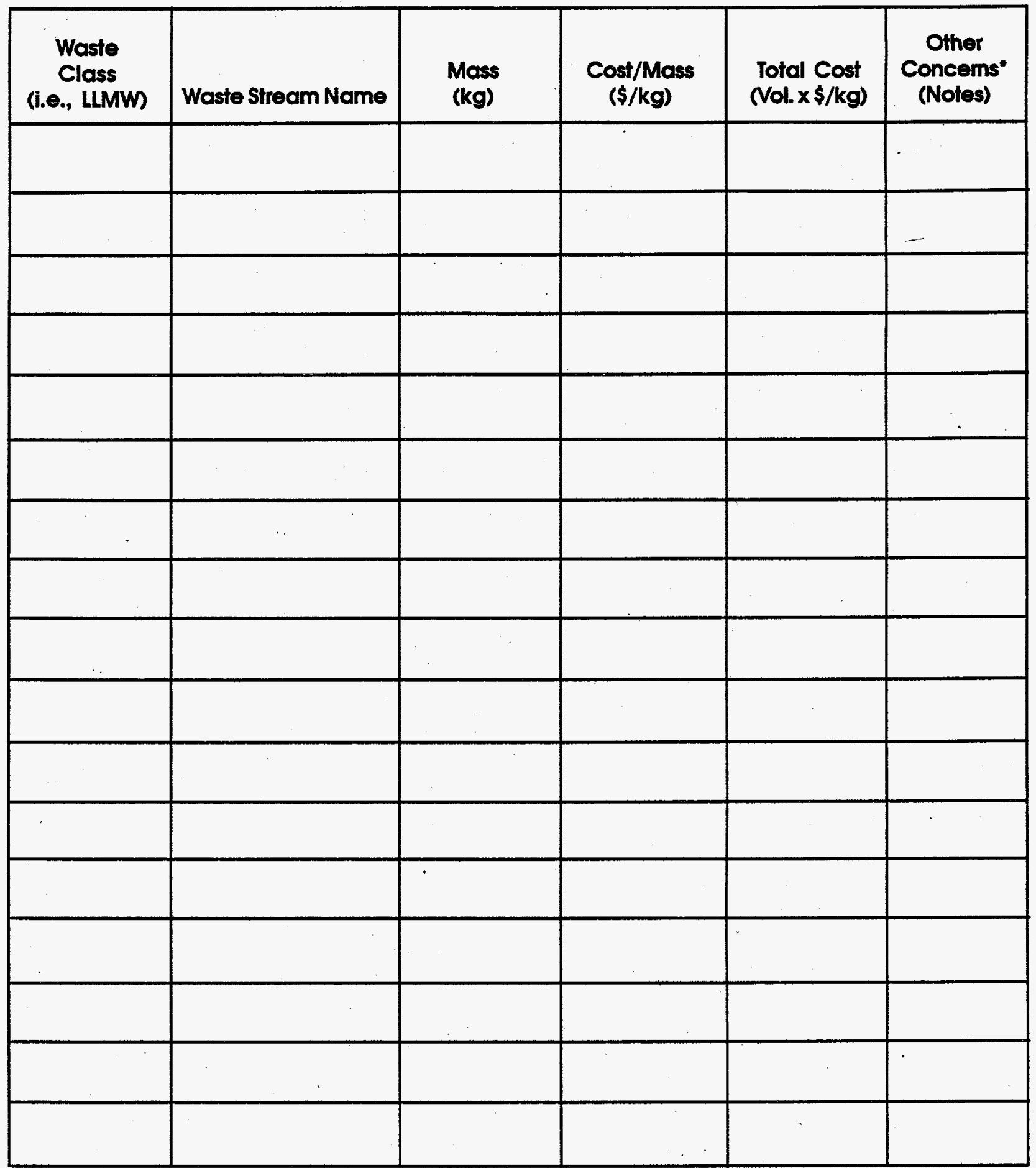




\section{Guidelines for Waste Stream Information}

This worksheet helps a P2 team prioritize waste streams and document summary information. Using the waste projections provided by Pollution Prevention:

1. Identify the three largest streams for each waste class. Record the waste class, the waste stream name, and the projected waste volume on the worksheet. Important sanitary waste streams can also be identified on this worksheet, if these are a priority or can easily be reduced.

2. Using the table below, identify the cost per mass (disposal cost) for each waste stream and record it in the Cost Per Mass column.

\begin{tabular}{|c|c|c|c|c|c|}
\hline Waste Class & LLW & LLMW & TRU & Hazardous & Sanitary \\
\hline$\$ / \mathrm{kg}$ & $\$ 1.76$ & $\$ 5.08$ & $\$ 3.68$ & $\$ 1.87$ & $\$ 0.07$ \\
\hline
\end{tabular}

3. Multiply the projected waste quantity of each waste stream by the volume cost of the waste and enter the amount in the Total Cost column.

4. Identify any other factors ${ }^{*}$ to be considered with the individual waste streams and record a key word for this factor in the Other Concerns column. P2 teams will have to determine the weight given these other factors. The Other Concerns column is designed to provide flexibility for teams to attend to specific management or environmental priorities.

*toxicity, regulatory, safety, ALARA, etc. 
WHC-SD-WM-EV-014, Rev. 2

\section{Priority Streams and Activities}

\begin{tabular}{|l|l|l|l|l|l|l|}
\hline $\begin{array}{c}\text { Prioritized Waste } \\
\text { Streams }\end{array}$ & Activity \#1 & $\%$ & Activity \#2 & $\%$ & Activity \#3 & $\%$ \\
\hline & & & & & & \\
\hline & & & & & & \\
\hline & & & & & & \\
\hline & & & & & & \\
\hline & & & & & & \\
\hline & & & & & & \\
\hline & & & & & & \\
\hline
\end{tabular}




\section{WHC-SD-WM-EV-014, Rev. 2}

\section{Guidelines for Priority Streams and Activities}

With the waste streams identified, the P2 team is ready to prioritize the streams and major activities generating them.

1. Prioritize waste streams identified on the Waste Stream Information Worksheet by highest total cost, accounting for other appropriate prioritizing factors*. Order these on the Priorities Streams and Activities Worksheet.

2. Identify the major activities generating each of these waste streams. While the form allows identification of the top three waste stream producing activities, more or less activities can be identified as appropriate. It would also be appropriate to list on this worksheet activities that could easily be changed to achieve waste reduction, e.g., "low hanging fruit".

This step will involve contacting key individuals in the facility. Important individuals to begin with would be the hazardous materials coordinator and the Environmental Compliance Officer.

3. Determine the approximate percentage of waste each activity contributes to the total waste stream. Enter this amount in the \% column.

*toxicity, regulatory, safety, ALARA, etc. 


\section{Pollution Prevention Opportunity Assessment WORKSHEET 1 Team \& Activity Description}

Date: P2OA ID Code: Facility:

Activity:

Team Members ( ${ }^{*}$ Leader) Telephone

Description of Activity to be Examined in this P2OA 


\section{WHC-SD-WM-EV-014, Rev. 2}

\section{Guidelines for Worksheet 1}

This worksheet provides the scope and identification of the pollution prevention opportunity assessment (P2OA) team. For the P2OA to be successful, employees involved with the activity being assessed should be members of the team. The assessment team needs a leader, members, and additional resources, as required.

The team leader should have technical knowledge of the area's operations and the personnel involved. The leader assembles the team to perform the assessment. Team members may include engineers, waste generators, waste management specialists, scientists, operators, laboratory technicians, and other line personnel. Additional resources may be utilized to provide information not available within the team, including interviews with line personnel, procurement and health and safety, as well as research of technical publications/case studies. The size of the team may be large for complicated operations, but should be kept to a minimum to maintain focus.

1. Date: List the initiation date for this P2OA.

2. P2OA ID Code: List the P2OA ID Code selected by the team or facility. This should be a unique identifier.

3. Facility: List the facility in which this P2OA is being examined.

4. Activity: List the activity contributing to the waste stream.

5. Team Members, Phone, MSIN: To facilitate team meetings and for future reference, this information should be completed when the P2OA team is formed.

6. Activity Description: This section should list the main activities contributing to the waste stream that are to be examined in this P2OA. Remember that this waste stream can be examined again in a future P2OA with a different activity focus, so limit the activities to be examined in a single P2OA to no more than three. If activities are very diverse, complete separate worksheets for each. A description of each activity should be listed, including pollution prevention activities already in place. Be sure and include the purpose or goal of the activity, schedule or frequency of activity, materials used, steps taken to complete the activity, and all wastes generated by each step. Items such as equipment, controls, operators, and operator training (qualification or certification) may also be included. 
WHC-SD-WM-EV-014, Rev. 2

\section{Pollution Prevention Opportunity Assessment WORKSHEET 2 Activity Flow Diagram}

Date: P2OA ID Code: Facility:

Activity:

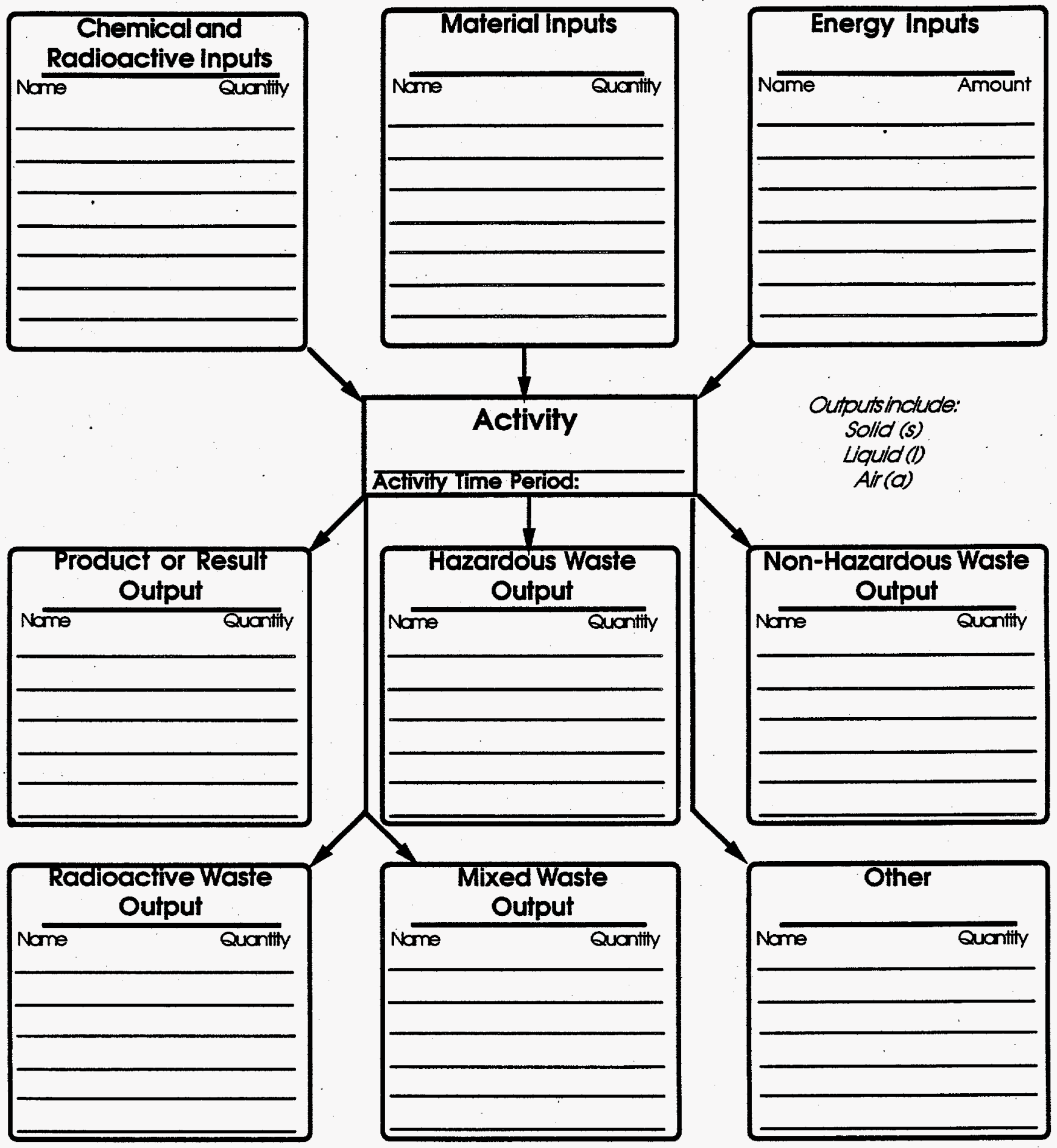

Total Input mass $\approx$ Total Output mass? $\mathrm{kg} \ln \approx$ $\mathrm{kg}$ Out 


$$
\text { WHC-SD-WM-EV-014, Rev. } 2
$$

\section{Guidelines for Worksheet 2}

This worksheet provides a method to document the activity flow diagram for the assessment. The flow diagram should identify all inputs (materials/resources) and outputs (products/wastes). The flow diagram should track materials from the time they enter the process boundary until they leave. This diagram represents a very simplistic flow model and is meant to be a guideline. If desired or if the activity is very complex, a more detailed diagram may be completed to identify all waste streams, especially for complex, multi-step processes. Several forms can be completed if several activities contribute to the waste stream of interest.

Please note that, although the focus may be on one priority waste stream, an analysis should be conducted on all material inputs and outputs. This is because the reduction of one waste may affect others in the activity (and you want to take credit for those too!). Additionally, while looking at an activity, it is cost and time effective to look at all waste streams and materials for possible reduction opportunities.

1. Date, P2OA ID Code, Facility, Activity: List the date this sheet is completed, the unique P2OA ID code, facility, and the examined activity for this P2OA from Worksheet 1.

2. Activity: Fill in the Activity Name box with the activity being examined.

3. Activity Time Period: List the time period for the activity being examined, such as, the complete clean-up, one analysis, yearly, etc.

4. Inputs: List the input materials on the lines provided, including hazardous materials, non-hazardous materials, and energy sources. Don't forget to include resource inputs such as water, cleanup supplies, reusable supplies, anything that ends up as a waste, is used and cleaned, or is used up during the activity.

5. Outputs: Fill in the outputs, both useful items and wastes, in the boxes. Include all manifested and non-manifested wastes, plus air emissions, if any.

6. Material Balance: A rough material balance can be conducted (making sure the inputs equal the outputs), to determine if most of the input and output materials have been captured. Energy inputs will not be included in the material balance. 
WHC-SD-WM-EV-014, Rev. 2

\section{Pollution Prevention Opportunity Assessment WORKSHEET 4 \\ Pollution Prevention Opportunities Summary}

Date: P2OA ID Code:

Facility:

Activity:

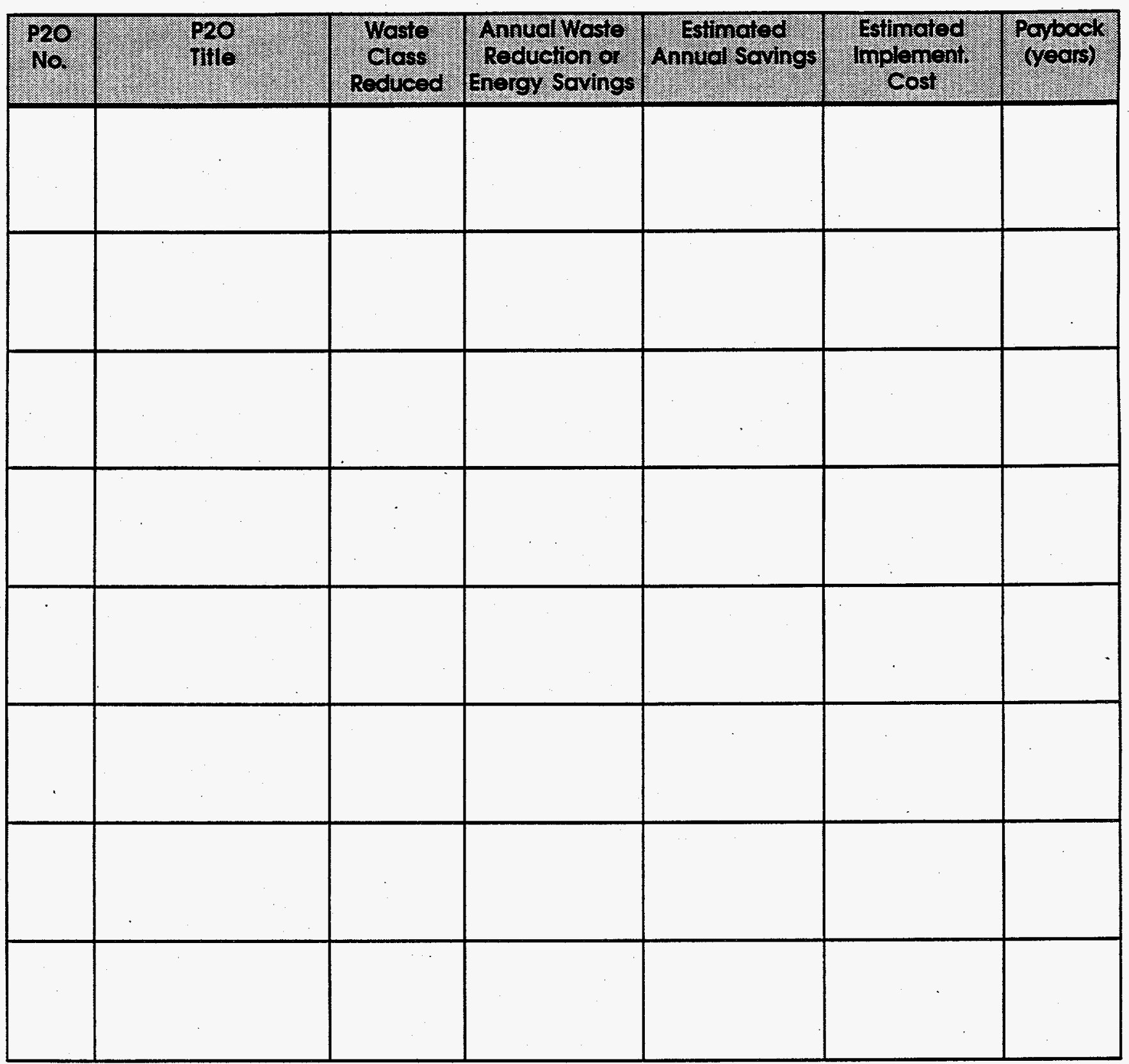

Notes and Other Benefits: 


\section{WHC-SD-WM-EV-014, Rev. 2 \\ Guidelines for Worksheet 4}

This worksheet is meant as a simple way to compare the P2Os with each other after the research and feasibility analysis has been completed. They can be listed according to the P2 hierarchy (source reduction first, followed by recycling/reuse, and treatment). They can also be listed according to the shortest payback, either within each hierarchy level or overall.

1. Date, P2OA ID Code, Facility, Activity: List the date this sheet is completed, the unique P2OA ID code, facility, and the examined activity for this P2OA from Worksheet 1.

2. P2O No., Title, Waste Class, Reduction, Savings, Implementation, and Payback: These values can all be entered directly from the sections in Worksheets 3 . If a savings or a implementation cost is very small, write 'negligible.' Just because an idea is not cost-effective or a large waste reducer, does not mean it should not be listed-it may be a simple"low-hanging fruit" that can be accomplished giving instant success or good public relations. Some ideas may ease compliance with regulations, or resolve a safety concern and thus should be considered also.

3. Notes and Other Benefits: The notes section can include any regulatory drivers for a particular $\mathrm{P} 2 \mathrm{O}$ or other important issues besides cost or P2 hierarchy to be considered. 
WHC-SD-WM-EV-014, ReV. 2

\section{Pollution Prevention Opportunity Assessment WORKSHEET 5 Final Summary}

Date: P2OA ID Code:

Facility:

Activity:

Proposed Opportunities and Discussion:

Recommendations \& Schedule for Implementation: 


\section{WHC-SD-WM-EV-014, Rev. 2}

\section{Guidelines for Worksheet 5}

This sheet provides a brief summary about the whole assessment. Its purpose is to document how this assessment was performed, the conclusions reached by the team, and the recommendations for further actions. For a more complex assessment, a longer, more formal executive summary may want to be written out for presentation to management.

1. Date, P2OA ID Code, Facility, Activity: List the date this sheet is completed, the unique P2OA ID code, facility, and the examined activity for this P2OA from Worksheet 1.

2. Proposed Opportunities and Discussion: Briefly describe the main opportunities examined, including the waste streams or input material to be minimized, benefits achieved, and any positive and negative aspects to the opportunities.

3. Recommendations \& Schedule for Implementation: Briefly describe any actions that should or will be taken in respect to this assessment. Provide a recommendation for date of implementation. 
WHC-SD-WM-EV-014, Rev. 2

APPENDIX D

WASTE MINIMIZATION/POLLUTION PREVENTION CERTIFICATION FORM

\section{WHO MUST COMPLETE THIS FORM?}

This report must be completed by waste generators that engaged in waste producing activities during the reporting period (January 1 - December $31,1994)$.

This information will be used to prepare reports required by the DOE, Ecology, and EPA. Please keep a reference copy in your program documentation file.

\section{MINIMIZATION OF EPCRA (formerIy SARA) REPORTABLE CHEMICALS}

If your facility uses any of the chemicals, and/or hazardous substances containing these chemicals, then provide projected minimization quantities for the years indicated.

Chemical

Chlorine

$\underline{1995}$

$\underline{1996}$

Lead

\section{CERTIFICATION:}

[ ] No waste reduction was achieved during 1994 (Obtain certification, do not complete the Generator Group Waste Minimization Reporting Form).

[ ] Waste reduction was achieved during 1994 (Please complete one reporting form for each waste stream that was reduced or minimized and attach it to this certification form.)

(Facil ity Name)

For the generator group(s) listed above, I certify that I have personally examined and am familiar with the information submitted in the attached document, and that based on my inquiry of those individuals immediately responsible for obtaining the information, I believe that the submitted information is true, accurate, and complete.

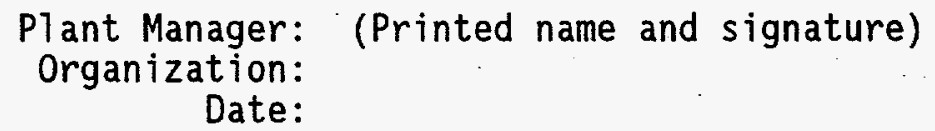


Facility/Location

Facility Contact* Name/Phone \#

Waste Stream Name

Type of Stream:

$\begin{array}{lllllll}\text { [ ] } & \text { HLW } & \text { [ ] TRU } & \text { [ ] TRU-Mixed } & \text { [ ] LLW } & \text { [ ] LLW-Mixed } \\ \text { [ ] RCRA } & \text { [ ] TSCA } & \text { [ ] TSCA-Mixed } & \text { [ ] State } & \text { [ ] Sanitary }\end{array}$

*Contact should be familiar with details of activity being reported.

INSTRUCTIONS:

Photocopy and complete this report for each waste stream minimized in 1994 (or use WordPerfect.)

Throughout this report enter "DK" if the information requested is not known or is not available; enter "NA" if the information requested is not applicable. Indicate if information is an estimate.

\section{SECTION I - WASTE REDUCTION ACTIVITY DESCRIPTION}

A. Please provide a complete narrative of the waste minimization activity. Include the reason for initiating the activity, what was reduced and the actions that enabled the reduction of waste. For source reduction and recycling activities, identify the appropriate EPA Waste Minimization Activity code (attached).

B. Waste minimization approach

What was the method used to reduce the volume (mass) or toxicity of waste? (Check all applicable boxes)

[ ] Source reduction

[ ] Recycling

[ ] Treatment techniques

C. Waste quantity avoided

Radioactive/mixed

Hazardous/sanitary $\mathrm{m}^{3}$.

$\mathrm{Kg}$.

[ ] Density of waste Units

or [ ] Specific gravity

D. Onsite/offsite recycling (skip to Section $2 F$ if recycling is not the waste minimization approach)

Quantity recycled onsite in 1994

Quantity recycled offsite in 1994 
E. Did waste minimization result in a change of the degree of hazard or toxicity associated with this waste?

[] Nos: [ ] Increase[ ]Decrease

E1. If yes, describe whether the change was in:

[ ] Concentration of hazardous constituents

[ ] Substitution of constituents

[ ] Both concentration of hazardous constituents and substitution of constituent.

F. What was the dollar amount of expenditures devoted to this waste minimization activity?

$\$$

G. Did this waste minimization activity result in cost savings?

[ ] Yes (explain in comments) [ ] No

comments (include estimated \$ savings):

\section{SECTION II - DESCRIPTION OF WASTE REDUCED}

A. Describe waste minimized (provide state, EPA hazardous waste codes, constituents, $\mathrm{pH}$, flashpoint, if applicable). If there are changes in waste codes after reduction activity, please indicate the change.

B. Waste form/physical state

[ ] Liquid[ ] Gas

[ ] Solid[ ] Sludge

C. Waste source description

Is waste result of:

[ ] Routine operations such as production, service or maintenance activities, or waste management

[ ] Non-routine such as D\&D or backlog waste processing.

E. Quantity generated prior to treatment, disposal, or recycling activities.

1993

1994

If the quantity in 1994 is more or less than the quantity in 1993, provide an explanation on what caused the change. 
WHC-SD-WM-EV-014, Rev. 2

This page intentionally left blank. 


\section{RECYCLING ACTIVITY}

W01 On-site recycling began during 1995

W02 Off-site recycling began during 1995

\section{SOURCE REDUCTION ACTIVITY}

\section{Good Operating Practices}

W11 Began to segregate types of hazardous waste to make them more amenable to recycling

W12 Began to segregate (stopped combining) hazardous waste from non-hazardous waste (Note: ' for purposes of hazardous waste reporting, reduces volume of hazardous waste, but does not reduce total waste volume)

W13 Improved maintenance scheduling, recordkeeping, or procedures

W14 Changed production schedule to minimize equipment and feedstock changeovers

W19 Other changes in operating practices (Specify in Comments)

Inventory Control

W21 Instituted procedures to ensure that materials do not stay in inventory beyond shelf-life

W22 Began to test outdated material-continue to use if still effective

W23 Eliminated shelf-life requirements for stable materials

W24 Instituted better labelling procedures

W25 Instituted clearinghouse to exchange materials that would otherwise be discarded

W29 Other (Specify in Comments)

Spill and Leak Prevention

W31 Improved storage or stacking procedures
W32 Improved procedures for loading, unloading, and transfer operations

W33 Installed overflow alarms or automatic shut-off valves

W34 Installed secondary containment

W35 Installed vapor recovery systems

W36 Implemented inspection or monitoring program of potential spill or leak sources

W39 Other (Specify in Comments)

Raw Material Modifications

W41 Increased purity of raw materials

W42 Substituted raw materials

W49 Other (Specify in Comments)

Process Modifications

W51 Instituted closed-loop recycling

W52 Modified equipment, layout, or piping

W53 Changed process catalyst

W54 Instituted better controls on operating conditions (flow rate, temperature, pressure, residence time)

W55 Changed from small volume containers to bulk containers to minimize discarding of empty containers

W58 Other (Specify in Comments) 


\section{BOOK 2: GUIDEBOOK AND CODES}

Rev. 2

Cleaning and Degreasing

W59 Modified stripping/cleaning equipment

W60 Changed to mechanical stripping/cleaning devices (from solvents or other materials)

W61 Changed to aqueous cleaners (from solvents or other materials)

W62 Reduced the number of solvents used, to make waste more amenable to recycling

W63 Modified containment procedures for cleaning units

W64 Improved draining procedures

W65 Redesigned parts racks to reduce dragout

W66 Modified or installed rinse systems

W67 Improved rinse equipment design

W68 Improved rinse equipment operation

W71 Other (Specify in Comments)

Surface Preparation and Finishing

W72 Modified spray systems or equipment

W73 Substituted coating materials used

W74 Improved application techniques

W75 Changed from spray to other system

W78 Other (Specify in Comments)

Product Modifications

W81 Changed product specifications

W82 Modified design or composition

W83 Modified packaging

W89 Other (Specify in Comments)

Other Source Reduction Activity

W99 Specify in Comments 
WHC-SD-WM-EV-014, Rev. 2

APPENDIX E

POLLUTION PREVENTION PROGRAM DOCUMENTATION SCHEDULE

\begin{tabular}{|c|c|c|c|c|c|c|c|c|c|c|c|c|}
\hline Activity & \multicolumn{11}{|c|}{1995 to 1999} & $\mathbf{D}$ \\
\hline Establish annual goals & E & $/ 15$ & & & & & & & & & & \\
\hline $\begin{array}{l}\text { Establish/revise five-year } \\
\text { forecast }\end{array}$ & ש & $1 / 15$ & & & & & & & & & & \\
\hline Annual report/certification & G & $1 / 15$ & & & & & & & & & & \\
\hline $\begin{array}{l}\text { Establish resource requirements } \\
\text { in ADS for current fiscal year } \\
19 X X+2\end{array}$ & & & & $4 /$ & & & & & & & & \\
\hline Quarterly report & & & & & $4 / 15$ & & & $7 / 15$ & & & - $10 / 15$ & \\
\hline $\begin{array}{l}\text { Establish budget in MYPP for } \\
\text { next fiscal year }\end{array}$ & & & & & & & & & $9 / 1$ & & & \\
\hline $\begin{array}{l}\text { Conduct pollution prevention } \\
\text { opportunity assessments }\end{array}$ & & & & & & & & & & & & \\
\hline Maintain program documentation & & & & & & & & & & & & \\
\hline
\end{tabular}


WHC-SD-WM-EV-014, Rev. 2

This page intentionally left blank. 
WHC-SD-WM-EV-014, Rev. 2

\section{DISTRIBUTION}

Number of Copies

ONSITE

4 U.S. Department of Energy -

Richland Operations office

E. B. Dagan

A5-15

R. G. Holt

S. H. Wisness

A5-15

RL Public Reading Room

A5-15

A1-65

2 Hanford Environmental Health Foundation

S. Gilchrist

H1-77

T. W. Harrison

$\mathrm{HI}-77$

4 Bechtel Hanford, Inc.

D. K. Duvon

$x 5-55$

D. B. Encke

R. J. Landon

R. A. Lewis

$\times 5-53$

H4-80

H4-79

15 ICF Kaiser Hanford Company

R. L. Baker

S2-34

D. L. Barron

S2-12

H. L. Budweg

G7-11

B. J. Dixon

D. R. Herman

E. L. Lamm

R. E. Lynne

C. E. Marple

G7-33

S2-12

G4-10

G7-33

S2-34

R. K. McETroy

S2-34

J. H. Mizner

T3-28

A. D. Poor

L6-55

S. M. Samoray

L6-55

M. L. Sil1s

S2-12

D. E. Stocker

L8-10

M. E. Tenvooren

S2-53 
WHC-SD-WM-EV-014, Rev. 2

DISTRIBUTION (cont)

Number of copies

ONSITE

5 Pacific Northwest Laboratory

W. J. Bjorklund

P7-68

T. L. Kuusinen

K3-75

R. R. Nielson

P7-79

K. B. Selby

P7 -79

H. T. Tilden

P7-79

82 Westinghouse Hanford Company

D. Allison

R2-86

B. A. Austin

B2-30

G. D. Baasch

G1-56

C. S. Barr

T. G. Beam

T5-54

S6-70

H. L. Benny

L7-09

M. D. Betsch

B2-22

R. K. Biyandi

L5-31

D. M. Bogen

S6-65

J. F. Brown

G2-06

S. E. Campbe11

T4-05

F. J. Carvo

N1-41

R. D. Clements

S4-25

P. J. Crane

T3-28

K. H. Cronin

L6-36

J. D. Dederick

B2-16

J. L. Demarest

G2-06

R. G. Dieffenbaker

H6-01

D. S. Dutt

T. 0 . Els

L6-39

A2-50

B2-22

L. J. Estey

T5-50

D. J. Farquhar

B1-24

D. A. Faulk

G. W. Faulk

T5-54

T3-28

B. C. Floyd

D. L. Fischer

D. L. Flyckt

B2-22

Al-05

T7-39

R1-51

R2-54

C. J. Geier

L5-31

W. 0. Greenhalgh

SO- 46

P. R. Gunter

R1-51

R. D. Gustavson

$56-70$ 


\section{WHC-SD-WM-EV-014, Rev. 2 \\ DISTRIBUTION (cont)}

Number of copies

ONSITE

Westinghouse Hanford Company (cont)

M. J. Hall

T6-07

J. E. Ham

L6-40

W. H. Hamilton Jr.

N3-10

D. G. Hamrick

P. L. Hapke

R1-51

D. E. Hare

T4-05

J. R. Hilliard

S3-97

N. O. Hinojosa

S6-19

X0-35

J. J. Holmes

L5-55

M. B. Jaeger

L4-02

J. R. Kirkendall

B2-22

J. M. Kisielnicki

L6-13

G. J. LeBaron

S6-19

P. E. Lemargie

D. W. Lindsey

C. D. Lucas

B1-24

H4-21

$\mathrm{X} 0-35$

T5-54

K. S. McDowell

H. E. McGuire

G2-06

B3-63

D. S. Merry

B2-22

P. C. Miller

N2-04

A. S. Mortensen

G. L. Neer

T3-28

L6-13

D. H. Nichols

B2-22

F. H. Nunamaker

L6-36

R. A. Otte

E. A. Raney

G5-03

B2-22

D. E. Rasmussen

$\mathrm{N} 1-47$

R. A. Riggers

L. E. Russell

N1-58

J. A. Seamans

T. W. Seifert

R. M. Suyama

N3-06

N1-36

R1-51

H5-60

R. W. Szelmeczka

N1-73

T. C. Varljen

M. R. Vasquez

B2-30

T7-39 
WHC-SD-WM-EV-014, Rev. 2

\section{DISTRIBUTION (cont)}

Number of copies

\section{ONSITE}

\section{Westinghouse Hanford Company (cont)}

M. J. Vitulli

H. R. Vogel

E. C. Vogt

E. F. Votaw

D. J. Watson

Central Files

Document Clearance

Administration (2)

$\times 8-29$

L4-96

T5-50

G2- 02

$X 0-41$

L8-04

L8-ก7 
WHC-SD-WM-EV-014, Rev. 2

DISTRIBUTION (cont)

Number of copies

ONSITE

3 Pacific Northwest Laboratory

W. J. Bjorklund P7-68

T. L. Kuusinen K3-75

H. T. Tilden P7-79

68 Westinghouse Hanford Company

D. Altison

R2-86

C. S. Barr

T5-54

T. G. Beam

S6-70

M. D. Betsch

$\mathrm{B} 2-22$

R. K. Biyandi

D. M. Bogen

L5-31

J. F. Brown

S6-65

S. E. Campbe11

G2-06

F. J. Carvo

T4-05

P. J. Crane

N1-41

K. H. Cronin

T3-28

J. D. Dederick

L6-36

J. L. Demarest

B2-16

G2-06

R. G. Dieffenbaker

H6-01

D. S. Dutt

T. O. Els

L6-39

D. J. Farquhar

A2-50

D. A. Faulk

B1-24

G. W. Faulk

T5-54

D. L. Fischer

T3-28

D. L. Flyckt

A $1-05$

T7-39

M. M. Feucht

R1-51

D. W. Fritz

H6-22

C. J. Geier

R2-54

W. 0 . Greenhalgh

L5-31

P. R. Gunter

SO-46

R. D. Gustavson

R1-51

D. L. Halgren

S6-70 
WHC-SD-WM-EV-014, Rev. 2

DISTRIBUTION (cont)

Number of copies

ONSITE

Westinghouse Hanford Company (cont)

M. J. Hall T6-07

J. E. Ham L6-40

W. H. Hamilton Jr. N3-10

D. G. Hamrick R1-51

P. L. Hapke T4-05

D. E. Hare $\quad$ S3-97

N. 0. Hinojosa X0-35

J. J. Holmes L5-55

M. B. Jaeger L4-02

J. M. Kisielnicki L6-13

P. E. Lemargie B1-24

D. W. Lindsey H4-21

C. D. Lucas $\mathrm{X0}-35$

D. J. McBride T5-54

K. S. McDowe11 G2-06

H. E. McGuire B3-63

P. C. Miller N2-04

A. S. Mortensen T3-28

G. L. Neer L6-13

F. H. Nunamaker L6-36

R. A. Otte G5-03

D. E. Rasmussen N1-47

R. A. Riggers N1-58

L. E. Russell N3-06

J. A. Seamans N1-36

T. W. Seifert R1-51

R. M. Suyama H5-60

R. W. Szelmeczka N1-73 
WHC-SD-WM-EV-014, Rev. 2

DISTRIBUTION (cont)

Number of copies

ONSITE

Westinghouse Hanford Company (cont)

M. J. Vitulii

H. R. Voge 1

E. C. Vogt

E. F. Votaw

D. J. Watson

Central Files (2)

Document Clearance

Administration (3)

Document Processing and

Distribution (2)

$\times 8-29$

L4-96

T5-50

G2-02

$\mathrm{X} 0-41$

L8-04

H4-17

L8-15

Distr-4 